\title{
The Impact Of The Use Of Materials-Based Multicultural Media With The Quartet Card Towards The Attitude Of Student
}

\author{
D. K. Moehani \\ Universitas Negeri Surabaya \\ Surabaya, Indonesia \\ dwikiranamoehani@gmail.com
}

\begin{abstract}
The aims of the research is to analyze the influence of the use of multicultural based teaching materials with the media of quartet card on the attitude of student tolerance. Type of research is a quasi-experiment using a quantitative approach. The research design used adapted Nonequivalent Control Group. This study consists of three stages, namely the preparation stage, the implementation stage, and the final stage of the experiment. The results of the research as follows: 1. Achievement of indicators in the experimental class is higher than the control class, 2. The learning is done well; 3 . There are differences in learning outcomes in the realm of knowledge and tolerance in the experimental class and control class. The result of the research shows that there is a significant influence of the use of multicultural based teaching materials with the media of quartet cards on the attitude of student tolerance.
\end{abstract}

Keywords - multicultural based teaching materials, quartet cards, tolerance attitude

\section{INTRODUCTION}

Indonesia faces multidimensional challenges, one of which relates to the fact that Indonesia is a pluralistic country of ethnicity and culture. Indonesia is a country that is ethnically diverse peoples and cultures. In addition, Indonesia has a diversity of geographical, religious, social, cultural, cultural, culinary, and other conditions that characterize both the region and its tribe. This is what underlies Indonesia as a multicultural society.

The condition of multicultural society in Indonesia is like a double-edged sword, on the one hand, is a modality that can generate positive energy, but on the other hand, if diversity is not managed properly will be a destructive explosion that can destroy the structure and pillars of nationality. Problems arising out of diversity that is not managed properly can threaten the life of nation and State. Therefore, it is very important to instill the values of multicultural consisting of the values of Justice, tolerance and togetherness, other values corresponding to the soul of the nation of Indonesia.

Multiculturalism can develop well in training and educating on the next generation through education. Education will be demonstrated and train students of the importance of mutual appreciate against the differences within each student. Liliweri
(2005)[1] States that multiculturalism is an educational strategy that leverages the diversity of the cultural background of the students as one of the powers to shape the attitudes of multicultural and beneficial to establish a shared understanding of the top concepts culture, cultural differences, the balance, and democracy in the broad sense. Mahfud (2011) [2] States that education should able to provide an offer that enlightened, inter alia by means of designing materials, methods, and curriculum that are able to arouse the public's attitudes about the importance of tolerance, respect tribal differences, religion, race, ethnicity, and cultural communities multicultural Indonesia. Multicultural education is indispensable to resolve conflicts such as horizontal, tribal and racial diversity as well as vertical conflicts such as level of education, economic, socio-cultural nation of Indonesia.

The process to instill those values in multicultural education can be reached through a path of education within the family (informal), community (non-formal), and or schools (formal). Multicultural education in schools is based on the prevailing curriculum. The 2013 curriculum is developed based on the diverse Indonesian culture. Education is directed to building the modern life and build the Foundation for a better life of the nation in the future. Education prepares students not only cognitive aspects alone but with education expected to develop the skills and attitudes which can be applied in diverse societies. The expected attitude among others, the attitude of mutual acceptance, respect the values, culture, and beliefs are different.

Pluralism in schools is expected to become a means of interacting with students. Students learn to respect each other and accept differences. Activities to develop an attitude of tolerance are done through in-class learning as well as real-life practices outside the classroom. The values of tolerance are implicitly or explicitly implicitly implied. Subjects that have greater levels in the development of student attitudes and personality systematically and planned (explicit) instill tolerance to students.

Schools are required for multicultural concepts and ideologies to be understood and practiced in the students' daily lives. One of the subjects that can bridge abstract social science 
concepts with real societal social phenomena in the student environment is Social Science (IPS) subjects. IPS contains the concepts of diversity, solidarity, tolerance, mutual understanding and more. Teachers have the task of internalizing and forming student mindsets about the values of togetherness without diminishing or negating the differences.

Social Science education at the school level is basically aimed at preparing students as citizens with knowledge, skills, attitudes and values that can be used as the ability to solve personal problems or social problems and ability to take decision and participate in various social activities in order to become a good citizen (Sapriya, 2012) [3] . In order for planned and implemented learning to achieve optimal results in accordance with the objectives set, then the teacher should be able to choose the appropriate methods and learning media. Learning by any method will not work without something that can really make students feel happy and interested to learn. So that students do not get bored and surfeited in learning, then during the learning must use media that serves to deliver the material and can attract students' attention. Therefore, the selection of methods and media should be appropriate with attention to teaching materials and characteristics of students.

Social Science learning through the media card Quartet aimed to prepare students with a set of attitudes and skills that are needed in the cultural environment of their ethnic, cultural, national, and ethnic cultural other. A student who is in East Java has to be familiar with the culture of the ethnic groups themselves. In addition, students are also required to know the other ethnic cultures outside of his group. Social Science learning through the media card Quartet expected to shape the views of students about the life and increase the appreciation of diversity.

Research results Setiyorini \& Abdullah (2012)[4] stated the use of media card game Quartet on Social Science subjects with the material to know the development of production technology, communication, and transportation as well as experience using it can streamline the activities of teachers in learning so that they can enhance the learning motivation of students. The use of media Quartet card game on Social Science subject can increase the effectiveness of the activities of students in learning so that they can improve student learning outcomes. The effectiveness of the use of media card game Quartet on subjects IPS with the material to know the development of production technology, communication, and transportation as well as experience using it can improve student learning outcomes. Improvement of the learning outcomes based on the average value of the results of the study, so that it can be stated the use of media card game Quartet is very effective for applied Social Science subjects.

Based on some of the research and description above, it is necessary to study and empirical evidence about the influence of quartet card media for multicultural based teaching materials on the attitude of tolerance of elementary school students. Tolerance is important because it is the key to creating a conducive learning situation and conducive student social relationships. Tolerance can prevent conflict between students so that when in school students feel safe, comfortable, and calm in learning.

Based on the description of the background of the issues that have been raised, then the outline of the problem in this research is whether there is the influence of the use of materials-based multicultural media card with the Quartet towards the attitude of tolerance of students?

\section{METHOD}

This research uses experimental methods with quantitative approach. Research on methods of experimental research methods are used to locate a particular treatment influence against the other in conditions completely (Sugiyono, 2010) [5]. Arikunto (2010) [6] explains that experimental research is to evoke the onset of a situation or event, experiments were conducted with a view to seeing the result of a treatment.

This research is a research quasi-experiment due to resolve difficulties in determining the control group used in the study. Quasi-experiment is one that involves the design of the experimental variables related to given special treatment (manipulation) and one control group with different treatment after that test result (Nasution, 2011)[7] .

This experiment took two research groups, i.e. one group as a group of experiments and one group as a control group. To get the group, conducted pre-test to test the equality of the sample. This was done so that the ability of the students can be controlled so that the results of this experiment are the result of learning using learning materials with multicultural media card Quartet.

The procedures in this study consist of three phases, namely the preparatory stage, the stage of implementation, and the final stages of experimentation.

\section{Preparatory Stage}

Activities at the stage of preparation as follows:

a. Pre-observation research in SD N Jagir 1/393

\section{b. Compiled a research instrument}

Research instruments are learning tools (RPP, multicultural textbooks, quartet media, crossword puzzle media), pre-test and post-test questions, learning activity observation sheet, and attitude observation sheet.c. validation of instrument research

The subsequent research instruments are given to experts for review. The review is done by an expert using the validation sheet. The validation sheet contains the item that states the eligibility of the research based on the correctness of the format, the truth of the concept, and the truth of the language.

\section{Implementation Stage}

Early activities at the implementation stage are doing a pretest to determine the samples have the same initial capability, further define the random control group and 
experimental group. Next, the students are given learning by using learning materials-based multicultural. Class experiments using media card Quartet and the control class use media crossword puzzles. For learning to take place, the observer gave judgment against the attitude of students and learning implementation. After the entire study has been completed, the student class and grade control experiments were given reserved post-test.

\section{Final Stage}

The final step of the research is to process and analyze data in the form of pre-test, post-test, observation of learning, attitude observation during learning. The results of the analysis are used to answer the hypothesis that has been proposed and draw conclusions.

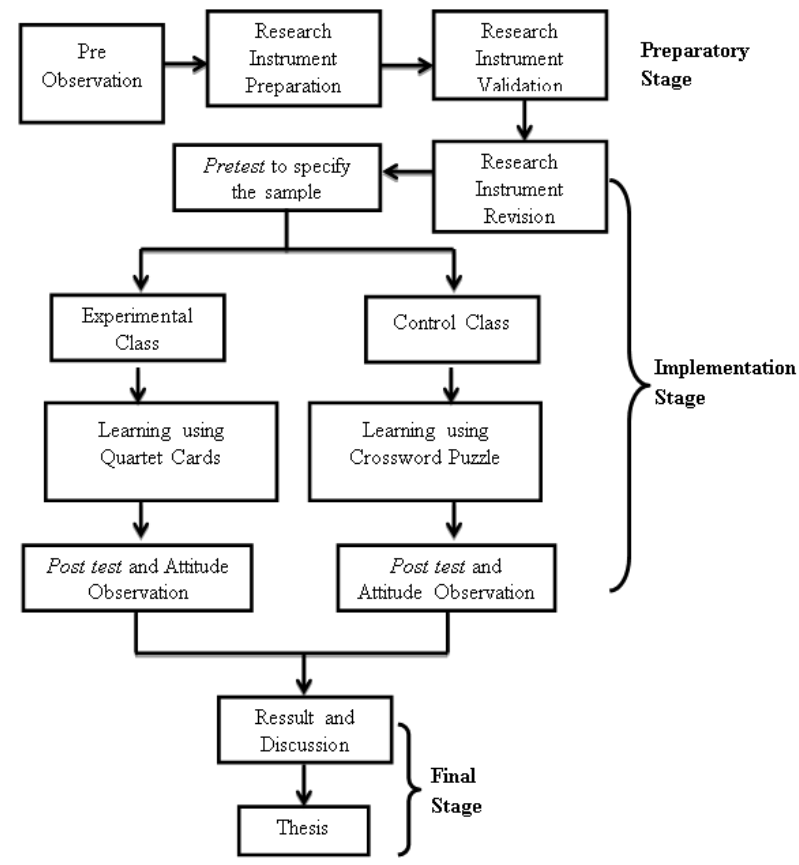

The samples in this study were students of SDN 1 Jagir / 393, which were 30 experimental class students and control class students of 30 people. The study was conducted in the even semester of the 2017/2018 school year, planned for April 2018.

Research variables are basically anything that shaped what is set by the researcher to be studied so that obtained information about it, then drawn conclusions. Variable in this study are:

\section{Independent Variable}

Independent variables are the variables that affect or be the cause of any such variables are bound. Independent variables in this research are the process of teaching and learning by using learning materials-based multicultural media card Quartet and crossword puzzles.

\section{Dependent Variable}

Depend variables are variables that are affected or which become due, because of the independent variables. Depend on variables in this study is the attitude of tolerance of students.

\section{Control Variable}

As for the controlled variables in this study, among other things:

a. Learning material is controlled by giving the same learning materials in both classes, namely multicultural materials.

b. The class that is used is of the same class, namely class IV.

c. The duration of treatment in both groups was controlled by the same amount of time.

d. Student's initial knowledge controlled through the pretest

Data collection techniques and instruments used, among others:

\section{Administering The Tests}

The written test is given to measure the attitude of tolerance in writing in accordance with the basic competence to be accomplished. The written tests are arranged in the form of multiple choice. The question of the written test consisted of 30 problems by providing four alternatives (a, b, c, and d). The test results in writing multiple-choice forms checked by giving a score of 1 for correct answers and score 0 for the wrong answer.

\section{Observation}

Observations were conducted to collect research data on the attitudes of students as well as the implementation of RPP during learning. The observation also observes the constraints that occur during learning. The observation is done by two people with observers using the same observation sheets. Before the observer doing observation, first described and trained how to charging sheets of observation, so expect the error does not occur at the time of the giving of the score (assessment).

The data of students tolerance attitude is obtained by observers observing the attitude that emerged during the learning activities took place. Observation sheet of tolerance is filled by the observer by giving a checklist $(\sqrt{ })$ on the available column when the aspect appears in the student. The RPP implementation data is obtained by observer giving checklist check $(\sqrt{ })$ on the observation sheet of RPP implementation if the planned step is executed. In addition, observers also provide an assessment of the implementation of the planned learning steps using a Likert scale. Observation sheet of learning implementation using a scale of $4,3,2$, and 1. Observer gives scores on observed learning performance. Data constraints on learning are obtained by observers observing the constraints that occur during the learning activities take place and write them on the obstacle observation sheet during the lesson. 


\section{Documentation}

Documentation is done on the teacher's daily journal. The journal contains notes about both good and bad students. The record is used to determine the value of student's attitudes.

\section{Questionnaire}

The questionnaire is used to express how much tolerance attitude of students in using the teaching materials based on multicultural media with the quartet card in the learning process. The questionnaire of tolerance contains twenty statements. Students provide checklist checks on the available fields. The questionnaire is arranged using a scale of $4-1$, is strongly agree: 4 , agree: 3 , less agree: 2 , and disagree: 1 .

\section{A. Instrumental Test}

Research instruments that are prepared to be used in research must meet the criteria of good instruments by fulfilling several tests, namely:

\section{Validity}

The research instruments should comply with logical validity and empirical validity. Logical validity is the validity of the instrument based on expert judgment. Data of logical validation results were analyzed descriptively qualitatively. Validity is determined the amount of passing grade which is the average score $(\mathrm{X} \overline{)}$ of the instrument assessment by some validator then determined the level of validity of assessment tools developed by matching the criteria. In addition to performing logical validity, empirical validity is also done by looking for a correlation between each question with the total score using the product moment correlation technique.

\section{Reliability}

Reliability is the same as consistency (Sukardi, 2003) [8]. A research instrument has a high-reliability value if the test made has consistent results in the measure to be measured. To test the reliability of the instruments in this study used Alpha Cronbach formula.

\section{Sensitivity Index}

The main characteristics of the criterion of reference criteria are reflected in the magnitude of the sensitivity index price indicating the effectiveness of the learning process (Basuki \& Hariyanto, 2014). The sensitive issue means that the problem can give information that the measurement is the result of the learning done. The sensitivity index is determined by the following formula:

\section{Difficulty Level}

Mardapi (2010) states that the level of difficulty is the correct proportion. The magnitude of this index is 0.0 to 1.0 . The acceptable level of grain difficulty is 0.30 to 0.80 . Problem level of the item can be calculated using the following equation:

The steps were taken in analyzing the research data by describing the data and testing the hypothesis. However, it is necessary to test the analytical requirements that include a normality test, linearity test, homogeneity test.

\section{B. Data of Description}

a. The effectiveness of multicultural teaching materials with the media of quartet cards

Effectiveness refers to the extent to which experience and outcome of the intervention are consistent with the intended purpose. The effectiveness of learning is viewed from the level of achievement of indicators by students.

$$
\text { Indicator achievement } \frac{\begin{array}{c}
\text { number of a student } \\
\text { reaching the aspect }
\end{array}}{\text { total of student }} \times 100 \%
$$

An indicator is achieved when $\geq 75 \%$ of students reach the completeness of the indicator

b. The practicality of multicultural teaching materials with the media of quartet cards

Practicality involves the implementation of learning. The criteria of each learning device implementation phase are marked checklist $(\sqrt{ })$ on the column and given a score 4 1. Data analysis technique is descriptively quantitative with the percentage of implementation as follows:

\section{Testing Requirements Analysis}

The terms, among others:

\section{Normally Test}

Normality test is used to test the data obtained normal distributed or not. To test the normality used tools using computer assistance SPSS 17.0 for windows program using Chi-Square formula.

The result of the hit $\left(X^{2}{ }_{\text {hit }}\right)$ is matched with $X^{2}$ table value at significant level $5 \% X^{2}{ }_{t, 5 \%}$ ). If the value $X^{2}{ }_{\text {hit }}<X^{2}{ }_{t, 5 \%}$ means the distribution of the data is normally distributed.

\section{Homogeneity Test}

The similarity test of two variances (homogeneity) aims to determine whether the sample comes from a homogeneous population or not by comparing the two variances. Test homogeneity using the following formula

\section{Hypothesis Test}

After the analytical requirements are met, the next step is to test the hypothesis. The hypothesis in this study is that there is the influence of the use of multicultural-based teaching materials with the media of quartet cards. Whether or not the influence of the use of multicultural based teaching materials with quartet card media on tolerance is known through the Independent-Sample TTest. The Independent-Sample T-Test was used to test the significance of the average difference between the two groups.

$\mathrm{H}_{0}$ : There is no influence of the use of multicultural based teaching materials with the media of quartet cards against tolerance 
$\mathrm{H}_{\mathrm{a}}$ : There is an influence of the use of multiculturalbased teaching materials with the media of quartet cards against tolerance.

The basis for decision-making is:

If $\mathrm{t}_{\text {hit }}>\mathrm{t}_{\mathrm{t}, 5 \%}$, means $\mathrm{H}_{0}$ rejected and $\mathrm{H}_{\mathrm{a}}$ accepted

If $\mathrm{t}_{\text {hit }}<\mathrm{t}_{\mathrm{t}, 5 \%}$, means $\mathrm{H}_{0}$ accepted and $\mathrm{H}_{\mathrm{a}}$ rejected

\section{RESULT AND DISCUSSION}

This research is still in the preparation stage, namely the revision phase based on validation and test results of the instrument. Validation and trial in the form of learning devices and assessment tools used. Assessments are structured according to the learning experience that has been designed in the RPP. Assessment tools compiled include assessments for assessing attitudes consisting of self-assessment questionnaire of spiritual attitudes and social attitude assessment (tolerance attitude), assessment to assess the domain of knowledge consisting of multiple choice questions, and assessment to assess the skill domain consisting of assessment product and performance assessment.

\section{A. Instrument Test}

\section{Validity and Reliability}

Logical validity through expert review to assess material, construction, and language aspects. Experts are welcome to improve directly on the text of the instrument and provide criticism and feedback and provide judgment worthy of use without revision, feasible to use with a few revisions, worthy of use with many revisions, or not yet eligible to use.

Based on the validation results of material experts and media experts, then all research tools are declared valid very valid and feasible to use with a little revision. The learning videos used still need to be revised and refined to make them more appealing to use in learning.

In addition to performing logical validity, empirical validity is also done by looking for a correlation between each question with a total score using product moment correlation technique An instrument item is said to be valid if it has a large contribution to the total score using product moment correlation techniques. Empirical validity was obtained by conducting an instrument test of 20 students.

Based on empirical validity test, 16 items have a correlation with the strong category, 12 items have a correlation with enough category, and 2 items have a correlation with the low category. Based on these results, then two items with a low correlation declared void, ie items number 17 and 28. Based on the data obtained then analyzed, the degree of reliability of the instrument of 0.884 with a description of the high degree of reliability. It shows that the instruments used are reliable.

\section{Sensitivity Index and Level of Difficulty}

According to Aiken (Muhajir, 2001)[9] item is said to be sensitive to learning when the sensitivity index $\geq 0.3$, then the item is sensitive to the effects of learning. If the sensitivity index of the item is $<0.3$, then the item needs to be revised.[10] Mardapi (2010) states that the level of difficulty is the correct proportion. The magnitude of this index is 0.0 to 1.0 . The acceptable level of grain difficulty is 0.30 to 0.80 .

Based on the sensitivity index analysis, the sensitivity index of grains $0.30-0.80$ so that the whole item is considered sensitive. These results indicate that the items of the questions prepared are sensitive to the effects of learning. Based on the difficulty level analysis, the difficulty level of the grain is $0.03-00.85$ so that 16 items are an easy category, 12 items are in the moderate category, and 2 items are a difficult category. The level of difficulty of the items that are arranged follows the cognitive level of competence to be achieved. Competence to be achieved on this learning at the level of determining and modeling so that the item only at the level of $\mathrm{C} 1$ and $\mathrm{C} 2$. Hence the developed problem has the most difficult and moderate difficulty level. Based on the results of the analysis of difficulty level, the two items with easy categories (TK: 0.85) is aborted, ie item 17 and 28. The item is too easy so it is not good to use.

Based on the results of validation and test of the instrument, it is stated that the instruments are suitable for research. Item number 17 and 28 is declared void so it is not used in the research. The number of items to be used amounted to 28 items.

\section{B. Description of Research Data}

\section{Sphere of Attitude}

Based on the description of tolerance data, the experimental class has the highest grade 3.52 , the lowest value 2,23 , and the average value 2,92 with the good attitude (B) and control class has the highest score 3,74, the value the lowest was 2.18 , and the average score was 2.78 with good enough criterion (B-).

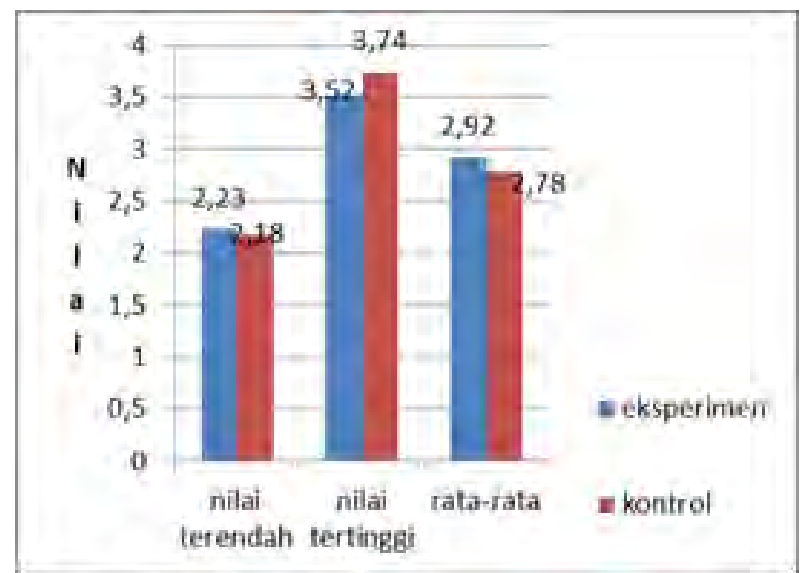

Image 1. Description of Tolerance Outcome Results 


\section{Sphere of Knowledge}

Based on the results of the knowledge domain description, in the pre-test, the experimental class has a minimum score of 3 , a maximum score of 7 , and an average score of 4.73 and the control class has a minimum score of 3 , a maximum score of 7 , and an average score of 4,77 . In the post-test activity, the experimental class has a minimum score of 18 , a maximum score of 28 , and an average score of 23.83 and the control class has a minimum score of 16 , a maximum score of 26, and an average score of 20.70 .

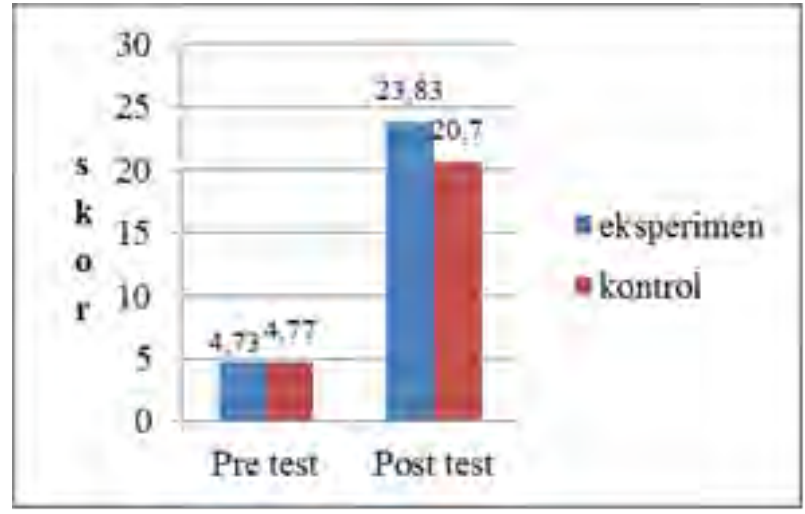

Image 2. Comparative Knowledge Range

\section{Sphere of Skill}

Based on the results of the skill domain description, on the performance skills, the experimental class has a minimum score of 8 , a maximum score of 12 , and an average score of 10.97 and the control class has a minimum score of 8 , a maximum score of 12 , and an average score of 9, 87. In product skills, the experimental class has a minimum score of 7 , a maximum score of 12 , and an average score of 8.37 and the control class has a minimum score of 6 , a maximum score of 9 , and an average score of 8 .

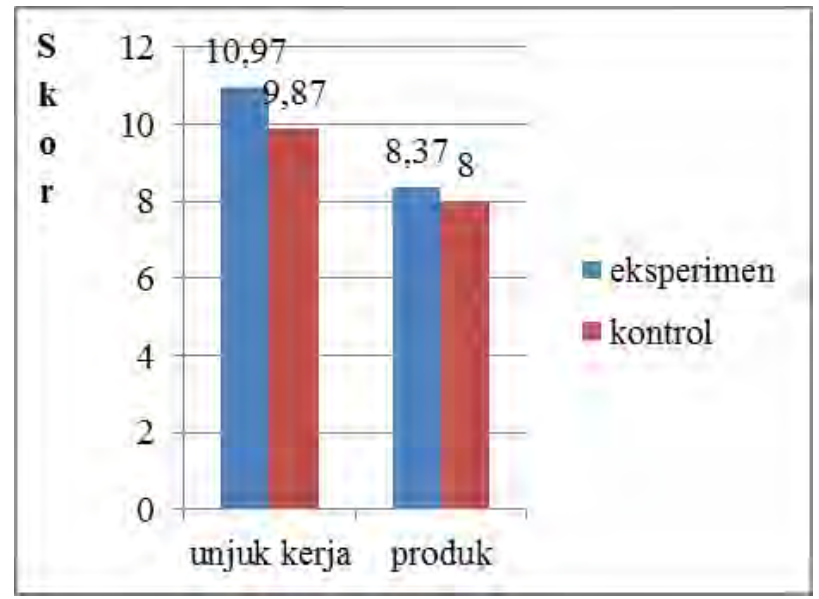

Image 3. Comparative of Skill Range

\section{Achievement of Indicator}

Based on the data of learning achievement indicators, the experimental class reached $92.85 \%$ with details of 26 problems reached and 2 problems not reached and control class reached $64.28 \%$ with details of 18 problems reached and 10 problems not achieved.

Based on the data analyzed, the students of the experimental class in the sphere of spiritual attitude are $100 \%$ complete, $93.33 \%$ tolerance aspect area, $86.67 \%$ knowledge area, 93,33\% performance skill area, and 100\% skill product skill. The students of control class in the sphere of $100 \%$ spiritual attitudes, the aspect of tolerance is $86.67 \%$, the realm of knowledge is $56.67 \%$, the performance skill is $83.33 \%$, and the skill is $96.67 \%$.

\section{Learning Implementation}

Based on the scores of learning implementation, learning I was done $100 \%$ every step that was prepared and got a score of 3.48 while learning II was done $100 \%$ every step compiled and got a score of 3.52 .

\section{Testing Prerequisite Analysis}

\section{Normality Test}

Normality test is conducted with the aim to test whether the distribution of distributed data is normal or not. The data normality test was performed using a Chi-Square test $\left(X^{2}\right)$. Next, the calculation $\left(X^{2}{ }_{\text {hit }}\right)$ is matched with table price $X^{2}$ at $5 \%$ significance level $\left(X^{2}{ }_{\mathrm{t}, 5 \%}\right)$. If the hit price $X^{2}{ }_{\text {hit }}<X^{2}{ }_{\mathrm{t}, 5 \%}$ means the distribution of the data is normally distributed. Normality test results are presented in Table 1 below.

Table 1.

Normality Test Result

\begin{tabular}{|c|c|c|c|c|c|}
\hline Kel & $\begin{array}{l}\text { Variabl } \\
\text { e }\end{array}$ & Db & $X^{2}$ hit & $X^{2}+, 5 \%$ & $\begin{array}{l}\text { Explan } \\
\text { ation }\end{array}$ \\
\hline \multirow{3}{*}{$\begin{array}{l}\text { Exper } \\
\text { iment }\end{array}$} & Pre test & 4 & 7,000 & 9,49 & Normal \\
\hline & $\begin{array}{l}\text { Post } \\
\text { test }\end{array}$ & 10 & 6,667 & 18,31 & Normal \\
\hline & $\begin{array}{l}\text { Toleran } \\
\text { ce } \\
\text { attitude }\end{array}$ & 17 & 9,600 & 27,59 & Normal \\
\hline \multirow{3}{*}{$\begin{array}{l}\text { Contr } \\
\text { ol }\end{array}$} & Pre test & 4 & 7,333 & 11,07 & Normal \\
\hline & $\begin{array}{l}\text { Post } \\
\text { test }\end{array}$ & 10 & 5,200 & 18,31 & Normal \\
\hline & $\begin{array}{l}\text { Toleran } \\
\text { ce } \\
\text { attitude }\end{array}$ & 14 & 7,000 & 23,68 & Normal \\
\hline
\end{tabular}

\section{Homogeneity Test}

The similarity test of two variances (homogeneity) aims to determine whether the sample comes from a homogeneous population or not by comparing the two variances. If the value of Sig. $>\square \square(0,05)$, then the group has the same variant value. Normality test results are presented in Table 2 below.

Table 2.

Homogeniety Test Result

\begin{tabular}{lll}
\hline Variabel & $\begin{array}{l}\text { Value } \\
\text { Sig. }\end{array}$ & Explanation \\
\hline Pre test & 0,868 & Homogen
\end{tabular}




\begin{tabular}{lll} 
Post test & 0,472 & Homogen \\
Sikap Toleransi & 0,144 & Homogen \\
\hline
\end{tabular}

\section{Hypothesis Test}

The presence or absence of the influence of the use of multicultural-based teaching materials with the media of quartet cards to tolerance is known through the IndependentSample T-Test. Independent-Sample T-Test test is used to test the significance of the average difference between the two groups.

H0: There is no influence of the use of multicultural based teaching materials with the media of quartet cards against tolerance

Ha: There is an influence of the use of multicultural based teaching materials with the media of quartet cards against tolerance.

The criterion used in this t-test is if $t_{\text {count }} \leq t_{\text {table }}$ or sig $>$ 0,05 then $\mathrm{Ho}$ is accepted, meaning there is no positive difference in pretest result of experimental group and control group. And vice versa, if $t_{\text {count }}>t_{\text {table }}$ or sig $<0,05$ then $\mathrm{He}$ is accepted, it means there is a positive difference in the result of learning IPS of the experiment group and control group. The t-test results are presented in Table 3 below.

Table 3.

Hypothesis Test Result

\begin{tabular}{|c|c|c|c|c|}
\hline Variable & $t$ count & t table & $\begin{array}{l}\text { Sig. (2 } \\
\text { Tailed) }\end{array}$ & $\begin{array}{l}\text { Explana } \\
\text { tion }\end{array}$ \\
\hline Pre-test & 0,341 & 1,671 & 0,734 & $\begin{array}{l}\text { No } \\
\text { differenc } \\
\text { e }\end{array}$ \\
\hline Post-test & 4,351 & 1,671 & 0,000 & $\begin{array}{l}\text { There is } \\
\text { a } \\
\text { Differenc } \\
\text { e }\end{array}$ \\
\hline $\begin{array}{l}\text { Toleranc } \\
\text { e } \\
\text { Attitude }\end{array}$ & 2,069 & 1,671 & 0,043 & $\begin{array}{l}\text { There is } \\
\text { a } \\
\text { Differenc } \\
\text { e }\end{array}$ \\
\hline
\end{tabular}

Based on the above table, the results of t-test calculations, pre-test results obtained $t_{\text {count }}$ of 0.341 and Sig. 0.734 ; post-test results obtained $t_{\text {count }}$ of 4.351 and Sig. 0.00; the result of tolerance attitude obtains a value of $t_{\text {count }}$ of 2.069 and Sig. 0.043 . Based on the result of $t$-the best there, is concluded that there is a significant difference of in knowledge and tolerance in the experimental group and control group.

Based on the results of hypothesis testing conducted, it can be concluded that there is the influence of the use of multicultural-based teaching materials with the media of quartet cards to the attitude of student tolerance. The effectiveness of the use of quartet media can be seen in the improvement of knowledge, attitude changes, and changes in student skills. Formation of attitude is not an instant, because to shape a person's attitude is influenced by many factors, including knowledge, experience, and environment. Therefore, the thing that is done is to provide sufficient knowledge to the students in advance in order to form a mindset according to the desired goals and provide experience supported by a conducive school environment in accordance with the attitude to be developed or cultured.

In addition to influencing the realm of knowledge and attitude, learning with multicultural teaching materials with the media of quartet cards influences the students' skills. Learning with the media of quartet cards makes the interaction between students and students to increase, in addition, the interaction between students and teachers also increases. This is shown by student activity during learning. Students appear to be more motivated by more active attitudes when learning. Learning with the media of quartet cards provides a stimulus for students to be more courageous and active in classroom learning. It is seen between the students of the experimental class and the students of the control grade of their performance skill score are higher in the experimental class.

Attitude is something that grows and develops in a person who is influenced by factors from within and outside factors so to make the attitude of tolerance into something that is entrenched culture is a continuous process by providing the right stimulus. Attitude is not only determined by the aspect of the individual but also determined by the values that exist in the group where the person is located. Therefore, teachers need to elicit or practice tolerant values in each group of students.

\section{CONCLUSION}

Based on the analysis of research data, discussion of research results and discussion of research results obtained, it can be concluded that there is a significant influence of the use of multicultural-based teaching materials with the media of quartet cards to the realm of knowledge and attitude of student tolerance.

\section{REFERENCES}

[1] A. Liliweri, Prasangka dan Konflik; Komunikasi Lintas Budaya Masyarakat Multikultur. LKIS PELANGI AKSARA, 2005.

[2] C. Mahfud, Pendidikan multikultural. Pustaka Pelajar, 2006.

[3] Sapriya, Pendidikan IPS Konsep dan Pembelajaran. Bandung: PT Remaja Rosdakarya, 2012.

[4] I. Setiyorini, "Penggunaan Media Permainan Kartu Kuartet Pada Mata Pelajaran IPS untuk Peningkatan Hasil Belajar Siswa di Sekolah Dasar," J. Penelit. Pendidik. Guru Sekol. Dasar, vol. 1, no. 2, 2013.

[5] Sugiyono, Metode penelitian pendidikan:(pendekatan kuantitatif, kualitatif dan $R \& D$ ). Alfabeta, 2008.

[6] S. Arikunto, Dasar-dasar evaluasi pendidikan. Bumi Aksara, 1999.

[7] Nasution, Kajian pembelajaran IPS di sekolah. Unesa University Press, 2011.

[8] P. D. Sukardi, "Metodologi Penelitian Pendidikan," Jakarta Bumi Aksara, 2003.

[9] M. Muhajir, "Upaya peningkatan kualitas pembelajaran IPA fisika SLTP dengan model problem based instruction," Univeritas Negeri Surabaya, 2001.

[10]D. Mardapi, "Pengukuran penilaian dan evaluasi pendidikan," Yogyakarta Nuha Med., 2012. 